\title{
Crude oil: using a large case to teach introductory economics
}

Citation for published version (APA):

Woltjer, G. B. (2004). Crude oil: using a large case to teach introductory economics. METEOR, Maastricht University School of Business and Economics. METEOR Research Memorandum No. 014 https://doi.org/10.26481/umamet.2004014

Document status and date:

Published: 01/01/2004

DOI:

10.26481/umamet.2004014

Document Version:

Publisher's PDF, also known as Version of record

\section{Please check the document version of this publication:}

- A submitted manuscript is the version of the article upon submission and before peer-review. There can be important differences between the submitted version and the official published version of record.

People interested in the research are advised to contact the author for the final version of the publication, or visit the DOI to the publisher's website.

- The final author version and the galley proof are versions of the publication after peer review.

- The final published version features the final layout of the paper including the volume, issue and page numbers.

Link to publication

\footnotetext{
General rights rights.

- You may freely distribute the URL identifying the publication in the public portal. please follow below link for the End User Agreement:

www.umlib.nl/taverne-license

Take down policy

If you believe that this document breaches copyright please contact us at:

repository@maastrichtuniversity.nl

providing details and we will investigate your claim.
}

Copyright and moral rights for the publications made accessible in the public portal are retained by the authors and/or other copyright owners and it is a condition of accessing publications that users recognise and abide by the legal requirements associated with these

- Users may download and print one copy of any publication from the public portal for the purpose of private study or research.

- You may not further distribute the material or use it for any profit-making activity or commercial gain

If the publication is distributed under the terms of Article $25 \mathrm{fa}$ of the Dutch Copyright Act, indicated by the "Taverne" license above, 


\title{
Crude oil: using a large case to teach introductory economics ${ }^{1}$
}

\author{
Geert Woltjer
}

April 152004

${ }^{1}$ I am very happy with the fruitful comments made by Erik de Regt, Tom van Veen and Maarten Vendrik on an earlier version of this paper. 


\begin{abstract}
This paper provides a sketch of a (140 hours) principles course in economics that is using the crude oil market as a case study. Such a case shows to students the relevance of economic principles in explaining real-world developments and policy issues. By using one large case instead of many small examples, the student gets a feeling for the complexity of the real world by building step by step a more complex vision of the market in its international environment. A long-term perspective may give students a feeling for the relativity of current short-term trends.

In this context it is important to show the application of the concepts in a realistic situation. Second, it is important that the most important concepts are applied in different contexts. Finally, it is important that the principles course is not focusing too much on technicalities that do not help directly in explaining the real world.
\end{abstract}

JEL classification: A20, A22

Keywords: teaching economics, undergraduate teaching, case-study, complexity vision 


\section{Introduction}

In an economic principles course students should learn to recognize problems that can be analyzed with economic principles, and to apply economic principles in order to understand the most important mechanisms shaping the real world. But the typical principles course "fails to improve economic literacy of not only those who take it, but also those frightened away by its reputation as a technical course. The course fails because it does not teach students how to apply economics to their personal, professional, and public lives." (Hansen, Salemi and Siegfried 2002: 464). In this paper it is argued that the crude oil market can be used as a large case to motivate students to investigate economic principles and to provide an opportunity to apply these principles.

In general, three types of improvements for the principles course have been suggested. First, a lot of authors argue that the content of economics courses should be changed. Becker (2003) suggests that principles courses should be focused on more "sexy" topics that are relevant in the "New Economy". This implies a reduction of the current content, leaving out technicalities. In a symposium to discuss Becker's article most authors suggest that a solid foundation in basic principles is required to understand the more difficult topics (Hamilton 2003, McMillin 2003, Siegfried and Sanderson 2003). Siegried and Sanderson (2003: 212) argue that the "enduring strength of the discipline has been its limited set of fundamental principles - opportunity cost, comparative advantage, trade-offs, specialization and exchange, incentives and marginal analysis, among others - that provide powerful insights when applied to a vast array of situations." According to Hamilton (2003: 199) "The difficulty lies in learning to believe that these answers are a useful guide to so many questions". So, the focus should be on a limited number of fundamental concepts and not on technical solutions, but there seems to be no reason to change the main concepts discussed in the principles course.

The second solution is the use of more varied teaching techniques, focusing on active student participation (see Becker 1997, Hansen, Salemi and Siegfried 2002). This may be very useful, and the course discussed here includes a lot of educational tools to stimulate active student participation (see Woltjer 2004). However, the focus of this article will be on yet another solution.

This solution is the use of real-world data and empirical evidence in the course: "To avoid simply dragging students to the conclusion (Becker's preaching), one needs to answer a lot of questions to get to the crucial points in studying real-world cases” (Hamilton 2003: 200). If students see that basic economics principles can explain important developments in the real world, this may help to create the feeling that economics is useful. The discussion of real-world examples may be very useful from this perspective. Such a case study approach may show students the relevance of economics and motivate them to study economic principles.

Consistent with Volpe (2002) I use the term "case study” in a broad way as real world examples, current or historical, that can be analyzed with economic theories and concepts and that may be relevant for policy recommendations to governments, companies or other institutions. So, the approach discussed here can be combined easily with more active student involvement (as is required in case studies defined in a more narrow sense), but can even be used in a lecture approach. A good case will show students that they need economics and will give them the opportunity to apply the theories.

Many courses use a large number of small case studies. Textbooks provide a lot of real world examples. This may help to see the relevance of theories discussed in a lot of different contexts, but is at the cost of a lack of depth and integration of those small case studies. A lot of students skip the real world examples provided in the textbooks, and if they read them, they don't have enough information and time to place them into their context. For this reason, one large integrated case may be more useful; students have more time to become familiar with the characteristics of the case at 
hand. Such a large case study may not only show the relevance of economics in the real world, but can also show the complex interrelationships between different aspects of the real world.

A large, integrated case study must be carefully chosen. It has to show the relevance of most topics in a principles course and must provide opportunities for immediate applications of these principles. It must generate interesting questions that have relevance for the current situation. The crude oil market is a very good case from this point of view. The oil market is regularly in the news, and the oil market is also related with macroeconomic and international developments. The immense fluctuations in oil prices during history and its relationship with politics make it a very challenging market. The oil market provides applications for almost every topic in an introductory course: supply and demand analysis, market power, oligopoly, game theory, economics of the public sector, the business cycle and exchange rate fluctuations, as will be shown below. The oil market is relevant for the strategy of companies that use a lot of energy as input, or that produce goods like cars that need oil as a complementary good. The oil market is also very relevant for government policy, both for OPEC countries and countries like the US and the Netherlands. The oil market is very complex, but this complexity can be developed step by step, as will be shown below.

A policy perspective on a case can improve the feeling by students that theories are relevant. When a course is designed for students in business a large international company seems to be an obvious choice. But you may also choose other types of companies, like car-producing companies and chemical companies, or a government policy perspective. My course starts with a large, international oil company, and discusses developments on the international oil market in combination with long-term international and national economic developments. The analysis of these developments from the perspective of the international oil company motivates the students to investigate almost all economic theories that are normally discussed in an introductory economics course, including a lot of topics that can be seen as being neglected in those courses (Becker 2000: 110).

In the remainder of this paper I will discuss the design of the course. The purpose of this discussion is to show how an introductory economics course centered on a large case can help students to develop a relatively complex and integrated vision on the world. The description is intended to show that the use of such a case can make economics more interesting for students. The course has been designed in a problem-based format (see Woltjer 2004), but other formats will do too. The remainder of the paper discusses the content of the course and shows how all aspects of an introductory economics course can be approached from the chosen extended case.

\section{Implementation of the case in the course}

The basic design of the course (my course is about 140 study hours) is to discuss the main areas of economic thinking (microeconomics, public sector economics, macroeconomics and international economics) from the perspective of an international oil company using the oil market in its international economic environment as a case study. This section will show how the oil market presents challenging problems relevant for both government and company policy that may guide the introduction and application of economic theory as discussed in most books on economic principles. We will describe the content of the course and show how the case provides an opportunity to build gradually a more complex picture of the oil market and the world economy.

The content of the course is relatively standard. We start with an introduction to scarcity and opportunity cost, and then go into microeconomics, including supply and demand analysis, market power, oligopoly and simple game theory. Then we discuss public sector economics and externalities. With respect to macroeconomics the labor market and monetary relationships are being discussed. Finally, the part about international economics discusses comparative advantage and alternative theories of trade as well as real exchange rates.

Introduction. The course starts with an introduction to the main case: the oil market from the perspective of a large, international oil company, as well as an introduction to the basic concepts of 
economics, scarcity and opportunity cost. First, citations from Shell's annual report may show the relevance of the oil market and international economic developments for Shell's strategy and performance. Related with this, the first challenging problem in the oil market may be introduced: at the start of the 1980s people expected oil prices to rise till about $\$ 100$ per barrel in the year 2000, while with hindsight \$20 per barrel would have been a better estimate. Around 1980 about \$500 billion were invested that were based on those incorrect price expectations (Clô, 2000: p XI). The principles of scarcity and opportunity cost can be used to explain the line of argumentation behind those predictions at the start of the 1980s.

Supply and demand analysis. The next step is to make the basic discussion about oil scarcity more precise through supply and demand analysis. A graph of the development of the real oil price since 1869 may be a good starting point for discussion. It shows that in 1874 the real oil price was more or less the same as the current real oil price. But despite its long-term price stability, in 1980 the real oil price was almost 10 times as high as the oil price in 1970. These large short-term fluctuations require an explanation. Supply and demand curves are a suitable instrument for such an analysis. In order to focus on supply and demand analysis we mention explicitly, that 'most forecasters project non-OPEC, non-communist production capacity and assume that it will all get to market' (Barry, 1993: 88), where OPEC production can be assumed to be exogenous. We ask students to explain changes in oil price as the consequences of a number of events (found on the website www.eia.doe.gov/emeu/cabs/chron.htm) with the help of supply and demand curves.

The next step is a deeper analysis of world oil demand and non-OPEC oil supply separately. A graph showing price and world oil consumption over time provides an incentive to think deeper about demand. After the two large price increases, world oil consumption decreased, while afterwards the growth of oil consumption was much lower than before. Students have to think about available substitutes in the short and long run, including isolation of houses, and indirect effects like recessions. They explain why the price elasticity of demand is much lower in the short run than in the long run and may investigate to what extent this explains the development of oil consumption. Because the short-term price elasticity of demand is very low, OPEC countries tended to underestimate the long-term effects of the high oil prices at the start of the 1980s.

The analysis of non-OPEC supply may focus on the relationship between technology, cost characteristics and behavior of oil producers. The technological characteristics of oil exploration and production, i.e. high fixed and sunk costs in combination with a very long time period between the decision to search for new oil and the actual production, explain the very low short-term price elasticity of non-OPEC oil supply and the much more elastic supply in the long run. But also other aspects of the oil market can be investigated. For example, at the start of the $20^{\text {th }}$ century oil refineries tended to be located near the production sites, while most are located near the consumption areas now, but recently the tendency returned in the direction of the production areas. This can be explained by differences in economies of scale in transport for crude oil versus refined oil products. Also the cost advantages of vertically integrated companies can be understood if students know that different qualities of crude oil require different refineries. It is obvious that the discussion must be focused on the basic concepts; a formal analysis is neither possible nor necessary in an principles course. Discussion of those problems already brings in some microeconomic principles not emphasized in textbooks, but highly relevant to decision-makers (Becker, 2000), such as bundling and complementarity's; expectations and risk, switching costs and lock-ins. The use of the large, real-world case automatically focuses attention on those parts of economics that are relevant in practice.

Market power and oligopoly. Although the concept of demand is relevant to explain world oil demand, and supply analysis is useful to analyze non-OPEC supply, the dynamics of the oil market is mainly determined by the market power of OPEC. The enormous profits generated by oilproducing countries after the two oil crises, in combination with the reduction in OPEC market share from $60 \%$ till $30 \%$ during the first half of the 1980 s provides a very challenging case to 
analyze the dynamics of market power, including the problem of cooperation. The discussion requires an extension of standard textbook theory with dominant firm oligopoly, or at least the idea that OPEC oil demand is the difference between world oil demand and non-OPEC oil supply. The discussion of OPEC market power requires application of all topics discussed before, including the difference between long and short-term price elasticities of supply and demand.

The stability of OPEC can be explained by changes in its market power (i.e. market share) as well as strategic aspects that can be analyzed as Prisoner's dilemmas. The change in the pay-off structure of the Prisoner's dilemma of the OPEC and the enormous differences in interest between the countries involved, explain the difficulty in finding a stable solution for the OPEC. It turned out that most countries became free riders.

Public sector economics. It is a very challenging question why most OPEC countries failed "turning black gold into development" (Van der Linde 2000: 31). Despite the enormous amount of money that came into the oil producing countries after the tenfold increase of the oil price in the 1970s, most countries remained relatively poor and even went into debt problems when oil revenues decreased during the 1980s. This may be a nice problem to start discussing government decisionmaking. Public choice types of argument may explain the lack of profitability of most investments in those countries, while overly optimistic expectations about the future of the oil price brought a lot of OPEC countries into debt problems. Those debt problems reinforced the coordination problem between the OPEC countries.

During the 1970s a lot of OPEC countries nationalized the oil companies. This provides an interesting starting point to discuss the ins and outs of private versus public decision-making. Most state producers in OPEC countries did not much to improve on their technologies of oil production, while the international oil companies experienced fast technological progress. The state oil companies depended for their finance on government, that wanted to use the money elsewhere. This implies that OPEC countries are becoming more and more dependent on international oil companies again (Van der Linde 2000, chapters 6 and 8), leading to privatization of state oil companies in the future. Such a case provides a nice insight into problems of the public sector, and at the same time shows the importance of those insights for large companies.

Externalities. Both sustainability problems and environmental problems like the Greenhouse effect are intimately related with the oil market. International oil companies like Shell and BP have a policy focused on sustainable development, partly inspired by the idea that in the not too far future oil may become scarcer. The scarcity problem can be better redefined as a problem of dependence on politically unstable Middle East countries. The policy formulation by Shell is used as a starting point for the discussion and automatically focuses on sustainability, externalities and its ethics. It was a surprise to me to see that a lot of business students focused their final paper on this type of problem.

Macroeconomics. The oil market may also provide a nice starting point for macroeconomic topics. The oil price increases in the 1970s stimulated wage increases in a lot of European countries, because labor unions wanted real wage increases, where the oil price was included in the basket to calculate inflation. This is a nice case to discuss price indexes and the concept of real income. A graph showing real labor cost, labor productivity and unemployment for a much longer period may provide a new challenge to apply supply and demand theory. The difference in reaction of labor cost to oil prices between Europe and the US is a nice illustration of the role of institutions in economic dynamics. High wages compared to labor productivity generated excess labor supply, where the effects of the high wages became only visible after a long period of time because of the difference between short and long-term elasticities. Just as with the OPEC countries, labor unions underestimated the long-term effects of high wages. So, the labor market provides the opportunity to apply the supply and demand concepts in a completely different context.

Also money can be introduced through the oil market. Monetary policy reacted completely different after the first oil crisis than after the second oil crisis. A graph showing developments in real 
interest rates, inflation rates and output gaps for some countries over time shows the spectacular changes over time and illustrates the difference in policy reactions: an increase in money supply after the first oil crisis against a tight monetary policy after the second oil crisis. Both a real interest rate of about $0 \%$ and a real interest rate of more than $6 \%$ at the start of the 1980 s are surprising and have enormous influences on the financial position of both companies and governments. The 1980s form a spectacular period to investigate more deeply, and illustrates with its combination of tight monetary policy, increases in government spending and tax reductions in the US almost every aspect of monetary economics that is relevant. It is obvious that also other episodes from economic history should be discussed, where students should be aware that the same basic scheme of reasoning can be applied over and over.

International economics. The change in location of oil refineries and oil production through time is the focal point of the theory of competitive advantage. Both technical, market and government policy aspects are relevant here.

The oil prices are formulated in dollars. This already makes the spectacular fluctuations in the real exchange rate of the dollar extremely important for the oil market. The rise in the real exchange rate, the rise in the real interest rate and the rise of the oil price explain a large part of the international debts crisis of the first half of 1980s. All those relationships are very much interrelated. The oil crisis was the occasion for the tight monetary policy, while this tight monetary policy generated the high real interest rates as well as the appreciation of the dollar. Most of the causal relationships can be understood with simple supply and demand curves, creating new opportunities to get a feeling for this very important instrument of economic analysis. And when students understand this basic relationship, a graph showing the development of the main long-term economic variables can be explained by a relatively small number of facts. In this way, they get, in combination with their principles course, a very short overview of some fundamentals of world economic history of the last forty years.

Also for macroeconomics the case automatically focuses on issues that are relevant from an empirical and decision-makers point of view. All the macroeconomic concepts that are, according to Becker (2000), being neglected in textbooks but important in the media, were automatically included in this course: nominal versus real interest rates, inflation rate differences and exchange rates, the loose tendency for real interest rates to be equal across countries, and the issue of technological change and economic growth.

In summary, the extended case study approach helps to integrate different parts of economics and puts them into a broader context. The necessity to use economic theory in explaining real world long-term developments automatically includes in the course economic aspects of the world that are neglected in textbooks but are empirically relevant. Furthermore, although the focus of the course is on economics, the setting is more or less interdisciplinary, and this may increase the appeal of the economics class (Cavilia-Harris 2003).

\section{Concluding comments}

In order to motivate students for introductory economics a course has been designed that is written from a (business) policy perspective, and focuses on topics and theories that are important from an economic point of view. The purpose of this paper is to show that it is possible to create a coherent structure to teach economics with the help of such a case study. The oil market in its international economic context is a case where almost every aspect of introductory economic theory can be applied. By using one large case instead of many small examples, the student gets a feeling for the complexity of the real world by building step by step a more complex vision of the market in its international environment. A long-term perspective may give students a feeling for the relativity of current short-term trends.

It is obvious that students need information about the case that is well-structured. In my course, students work in small groups starting with the problems discussed above. A website with a 
selection of relevant links, a reader with some articles about the oil market, and a general overview of empirical developments and some additional theoretical insights are provided to help students to relate economic theory to the complexity of the real world. We require students to write some small papers to digest and integrate the information.

By explaining long-term economic developments with the help of economic theory, the focus is automatically on those parts of economic theory that are relevant from an empirical point of view. The theme chosen, i.e. the oil market in combination with international macroeconomic developments, is relevant for all students, not only business students. The choice of a business perspective as a starting point for the discussion is specifically focused on business students, but it is not difficult to find another perspective for other courses. But even the business perspective did not prevent students to have a broader perspective. For example, sustainability problems and problems of macroeconomic stability entered automatically into the picture, because they are also relevant from a business perspective.

\section{References}

Barry, R. (1993), The Management of international oil operations, Pennwell books, Tulsa, Oklahoma.

Becker, W.E. (1997), 'Teaching economics to undergraduates', Journal of Economic Literature, 35, pp 1347-73.

Becker, W.E. (2000), 'Teaching economics in the 21st century', Journal of Economic Perspectives, 14(1), pp. 109-19.

Becker, W.E. (2003), "Economics: The Sexy Social Science? How to Make Economics the Sexy Social Science”, Southern Economic Journal, 70(1), pp. 195-225.

Caviglia-Harris, J.L. (2003), 'Introducing undergraduates to economics in an interdisciplinary setting, Journal of Economic Education, 34(3), pp 195-203.

Clô, A. (2000), Oil Economics and Policy, Kluwer.

Colander, D. (2000), The complexity vision and the teaching of economics, Edward Elgar.

Hamilton, J. (2003), 'Economics: The Sexy Social Science? Improving the Principles of Economics Course’, Southern Economic Journal, 70(1), pp. 198-201.

Hansen, W.L, Salemi, M.K. and Siegfried, J.J. (2002), 'Use it or lose it: teaching principles in the economics principles course’, American Economic Review (Papers and Proceedings), 92(2): pp 463472.

Linde, J.G. van der (2000), The state and the international oil market, Kluwer, Boston, Dordrecht, London.

McMillin, W.D. (2003), 'Economics: The Sexy Social Science? Is the Economics Major Dying and, If So, Will Changes in Teaching Technology and Course Content Save It?', Southern Economic Journal, 70(1), 206-209.

Siegfried, J.J.; Sanderson, A.R. (2003), 'Economics: The Sexy Social Science? Keeping Economics from Becoming a Sexy Social Science’, Southern Economic Journal, 70(1), 209-214.

Volpe, G.(2002), 'Case studies', in: Davies, P. (ed.) The Handbook for Economics Lecturers, section 1: teaching. http://www.economics.ltsn.ac.uk/handbook/casestudies/.

Woltjer, G.B. (1995), Coordination in a macroeconomic game: its design and its role in education and experiments, Thesis Rijksuniversiteit Limburg, Universitaire Pers Maastricht, ISBN 90-5278179-6.

Woltjer, G.B. (2002), De economische manier van denken, Coutinho, Bussum, 2nd edition (in Dutch) 
Woltjer, G.B. (2004), 'An efficient format for a problem based introductory economics course', Meteor Research Memorandum, Maastricht, forthcoming. 